\title{
The efficacy of ultrasonic irrigation technique on debris removal during root canal treatment
}

\author{
Jeong-Hyeon Kim, Jin-Woo Kim, Kyung-Mo Cho, Se-Hee Park* \\ Department of Conservative Dentistry, College of Dentistry, Gangneung-Wonju National University School of Dentistry, \\ Gangneung, Republic of Korea
}

Purpose: The purpose of this study was comparing the efficacy of passive irrigation (PI) and passive ultrasonic irrigation (PUI) for ability to remove debriment of canals. Materials and Methods: Mandibular premolars were decoronated and standardized to 16 $\mathrm{mm}$ length. After root canal enlargement and half separating longitudinally, standardized groove of $4 \mathrm{~mm}$ length, $0.2 \mathrm{~mm}$ width and $0.5 \mathrm{~mm}$ depth were formed on the dentin wall of one half. Three depressions in the canal wall of the opposite half, $0.3 \mathrm{~mm}$ in diameter and $0.5 \mathrm{~mm}$ in depth, were formed. After each groove and depression was filled with dentin debris, two sections of each half were reassembled using impression putty material. In group 1 the canals were irrigated with $2.5 \% \mathrm{NaOCl}$ by $\mathrm{PI}$. In group 2 the canals were irrigated with $2.5 \% \mathrm{NaOCl}$ by PUI. Before and after root canal irrigation, the root canal wall of the section was taken with a microscope and a digital camera as images. The amount of dentin debris remaining in grooves and depressions was assessed using a scoring system. Results: There was no significant difference between PI and PUI except for the middle $1 / 3$ of the root canal $(P=0.004)$. Conclusion: At the middle $1 / 3$ of the root canal, PUI removed more dentine debris than PI. But the removal efficiency of dentin debris is not significantly different between the PUI and PI at the apical area of root canal in mandibular premolars. (J Dent Rehabil Appl Sci 2017;33(2):97-105)

Key words: canal irrigation, dentine debris, mandibular premolar, passive irrigation, passive ultrasonic irrigation

\section{서론}

근관치료 시 가장 중요한 과정 중의 하나는 근관계를 기계화학적으로 성형하는 것이다. 근관 세정은 기계적인 기구조작과 함께 근관계로부터 치수 조직과 미생물, 잔 사와 도말층 그리고 gutta-percha, 근관 실러, 약제 등을 제거하는 데에 있어 상호보완적으로 작용한다. ${ }^{1}$

근관 세정의 효율성은 세정제의 조직 용해성과 기계 적인 flushing action에 달려있다. 차아염소산나트륨 $(\mathrm{NaOCl})$ 은 근관 내 유기조직을 용해하는 성질과 ${ }^{2,3}$ 항세 균성 작용 ${ }^{4}$ 으로 인해 근관치료학에서 60 여년 이상 근관

*Correspondence to: Se-Hee Park

Associate Professor, Department of Conservative Dentistry, College of Dentistry, Gangneung-Wonju National University, 7, Jukheon-gil, Gangneung, 25457, Republic of Korea

Tel: +82-33-640-2760, Fax: +82-33-640-3103, E-mail: drendo@gwnu.ac.kr Received: February 26, 2017/Last Revision: March 10, 2017/Accepted: April 21, 2017
\end{abstract}

세정제로서 널리 사용되어 왔다. ${ }^{5}$

근관 세척액의 flushing action은 근관으로부터 유기물 과 상아질 잔사, 미생물을 제거하는데 도움이 된다. 하지 만 수동적 세정에 의해 발생하는 활성화는 비교적 약하 고 근관계의 해부학적 형태와 바늘의 직경에 의해 효과 가 한정된다. ${ }^{6,7}$

세척액을 활성화 시키는 방법으로 여러가지가 시도되 었다. 잔사를 제거하는 효율성에 있어서 세척액의 양을 늘리는 것은 flushing action과 유의한 차이가 없으며, ${ }^{8}$ 현 재는 초음파를 이용한 방법이 많이 사용되고 있다. 초음 파 세정에는 Active ultrasonic irrigation (AUI)과 Passive

Copyright@ 2017 The Korean Academy of Stomatognathic Function and Occlusion. (c) It is identical to Creative Commons Non-Commercial License. 
ultrasonic irrigation (PUI)가 있다. AUI는 기계적 근관 형성과 세정을 동시에 시행하는 방법으로 근관벽의 손상 가능성과 효율성이 떨어진다는 단점이 있고, ${ }^{8,9} \mathrm{PUI}$ 는 초 음파로 인해 근관 내 세척액에 파일이 진동하며 에너지 를 전달하는 방식으로, 음향유동과 공동현상으로 도말 층과 상아질 잔사, 박테리아를 효율적으로 제거한다. ${ }^{10}$ 직선적이고 넓은 근관에서 초음파 세정을 했을 때 수동 적 세정보다 상아질 잔사를 더 많이 제거하는 것으로 알 려져 있다. ${ }^{10}$

기구조작이 안된 부위에 전통적인 수동 세정으로는 근 관 내의 잔사를 제거하기 어렵기 때문에 잔사와 박테리 아를 남기게 된다. ${ }^{11}$ 만약 기구조작이 안된 부위로부터 상아질 잔사를 완벽하게 제거하지 못한다면 불량한 결과 를 야기할 수 있다. 첫째로, 병원균과 직접적으로 접촉해 야만 기능하는 수산화칼슘과 같은 약제는 잔사가 차지 하는 공간에 놓이지 못하고, 그 결과로 약효가 떨어지게 된다. ${ }^{12}$ 둘째로, 잔사가 없는 부위만 gutta-percha와 근관 실러로 채워지기 때문에 잔사로 채워진 canal extension 은 누출의 결과로 이어질 수 있다. ${ }^{13}$ 확실히 모든 상아질 잔사를 제거하는 것은 근관치료의 필수적인 부분이다.

이에 따라 본 연구에서 근관 성형 및 근관 확대를 한 근 관계에 인위적으로 형성한 canal extension과 irregularity 에서 Passive irrigation (PI, syringe irrigation)과 Passive ultrasonic irrigation (PUI)의 잔사 제거 효율성에 대해 비교해보고 임상에서 안전하면서 보다 효율적으로 근관 을 세정할 수 있는 방법을 알아보고자 하였다.

\section{연구 재료 및 방법}

근관이 하나인 발거된 하악 소구치 30 개를 실험에 사 용하였으며 만곡이 심한 근관은 배제하였고 파절이나 미 세균열 같은 치아의 결함이 있거나 치근흡수가 되어 치 근단공이 넓어져 있는 치아 또한 표본에서 제외하였다.

근관의 길이를 일치시키기 위하여 치관부위를 삭제하 고 치근을 $16 \mathrm{~mm}$ 길이로 표준화하였다. 각 치아의 근 관 와동을 형성한 이후 실제 근관의 길이로부터 $1 \mathrm{~mm}$ 떨어진 부위까지 근관을 성형할 수 있도록 $15 \mathrm{~mm}$ 로 작 업장을 설정하였고, \#15 K 파일(Dentsply Maillefer, Ballaigues, Switzerland)로 기구의 첨단 부위가 치근단공 에 보일 때까지 삽입하여 patency 를 확보하고 glide path 를 형성하였다. 각 근관은 Protaper Universal system (Dentsply Maillefer, Ballaigues, Switzerland)의 Sx, S1,
S2, F1, F2, F3, F4 (Final size: \#40/.06)으로 작업장까 지 근관 형성 및 확대 시행하였다. 각 파일로 근관 형성 을 할 때마다 $12 \mathrm{~mL}$ Blue endo lock syringe \& 27-gauge tip (Kaili, Zhaoyuan, China)을 사용하여 2.5\% 농도의 $\mathrm{NaOCl} 2 \mathrm{~mL}$ 로 근관세정 하였다.

각 치아를 $0.15 \mathrm{~mm}$ 두께의 다이아몬드 디스크 (911HF; Komet, Lemgo, Germany) 를 사용하여 장축에 평행한 방향으로 구를 형성하고 chisel을 이용하여 종단방향으 로 두 개로 분리시켰다.

Sickle scaler (H6/H7; Hu-Friedy, Chicago, USA)의 작 업날을 사다리꼴 모양으로 연삭하여 가공하였다. 각 치 아의 분리된 한쪽 상아질벽에는 기구조작이 되지 않은 canal extension을 표현하기 위하여, sickle scaler를 사용 하여 치근첨에서 $2-6 \mathrm{~mm}$ 의 거리에 $0.2 \mathrm{~mm}$ 의 너비, 0.5 $\mathrm{mm}$ 의 깊이의 표준화된 구를 형성하였다(Fig. $1 \mathrm{~A}){ }^{14}$

치아의 반대쪽 상아질벽에는 canal irregularity를 표현 하기 위하여, 직경 $0.3 \mathrm{~mm}$ 로 연삭한 No. 1/4 round bur (H1.314.005; Komet, Lemgo, Germany)를 이용하여 치 근첨에서 2, 4, $6 \mathrm{~mm}$ 의 거리에 직경 $0.3 \mathrm{~mm}$, 깊이 0.5 $\mathrm{mm}$ 인 3 개의 반구 형태의 함요를 형성하였다(Fig. 1B).

실험군과는 별개로 종단적으로 분리한 치아의 근관벽 으로부터 직경이 1.4 mm의 No. 4 round bur (H1.314.014; Komet, Lemgo, Germany)를 사용하여 상아질을 삭제 하며 생성된 상아질 잔사를 만들고, $2.5 \% \mathrm{NaOCl}$ 과 5 분 간 혼합시켜 두어 sand-like mixture로 제작하였다. 실험 군의 각 구와 함요를 포함한 근관 내부에 음성대조군인 group 4 를 제외하고 $2.5 \% \mathrm{NaOCl}$ 과 인위적으로 만든 상아질 잔사 혼합물로 채운 뒤 절반으로 분리된 두 절편 은 $15 \times 15 \mathrm{~mm}$ 의 플라스틱 주형에 퍼티 인상재(Exafine Putty; GC, Tokyo, Japan)을 채워넣고 시편을 재조합하 여 묻은 뒤 경화시켰다.

이후 총 30 개의 치아를 가지고 4 군으로 나누어 세정 방법을 달리하여 실험을 진행하였다.

Group 1 ( $\mathrm{n}=10)$ 에서는 syringe를 이용한 수동적 세정 을 시행하였다. 27 - gauge tip으로 $14 \mathrm{~mL}$ 의 $\mathrm{NaOCl}$ 을 약 1분간 세척하였으며(irrigant delivery rate: $15 \mathrm{~mL} \mathrm{~min}^{-1}$ ), 작업장에서 $1 \mathrm{~mm}$ 짧은 $14 \mathrm{~mm}$ 의 길이까지 넣고 세척하 였다.

Group $2(\mathrm{n}=10)$ 에서는 $2.5 \% \mathrm{NaOCl}$ 과 UC-ONE \& UC-ONE tip (Epdent, Seoul, Korea)을 이용하여 수동 적 초음파 세정을 시행하였다. 먼저 $2 \mathrm{~mL}$ 부피의 $\mathrm{NaOCl}$ 로 세정하고 초음파 기구를 작동(20초간 진동) 한 뒤 다 

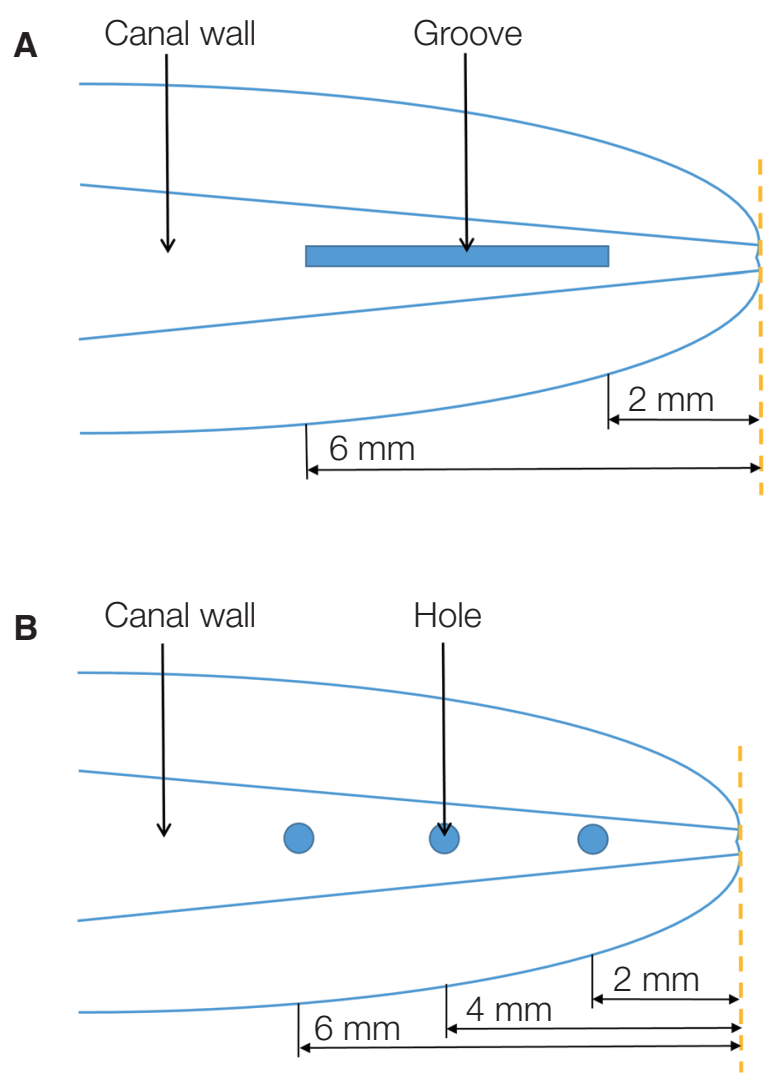
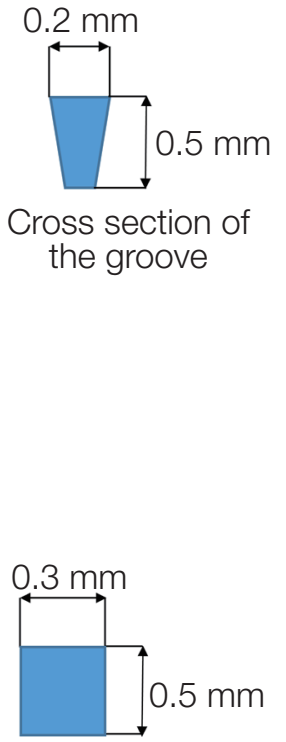

Cross section of the groove

Fig. 1. Schematic representation of specimen preparation. (A) On one half of the prepared root canal a groove was cut 2 to $6 \mathrm{~mm}$ from the apex, (B) On the other half three depressions were cut 2, 4 and $6 \mathrm{~mm}$ from the apex.

시 세척하고 초음파 기구를 다시 적용하였다. 최종 세정 시에 $10 \mathrm{~mL}$ 의 $\mathrm{NaOCl}$ 을 사용하였기에 전체적으로는 14 $\mathrm{mL}$ 부피의 세척액을 적용하였다. 초음파 기구의 tip은 작업장 보다 $1 \mathrm{~mm}$ 짧은 지점까지 위치시킨 후 진동시켰 다. 초음파 기구를 작동 시 20 초간 자동으로 진동이 되 고, 두 번 반복하여 총 40 초간 적용이 되었다. 제조사에 따르면 이 기구의 진동 주파수는 $30 \mathrm{kHz}$ 이다.

Group $3(\mathrm{n}=10)$ 은 양성대조군으로 설정하여 근관 내에 인위적으로 제작한 상아질 잔사를 채워 넣었으나 세정을 시행하지는 않았다.

Group $4(\mathrm{n}=10)$ 은 음성대조군으로 설정하여 근관 내에 상아질 잔사를 주입하지도 않았고 세정 또한 시행 하지 않았다.

이러한 세정 과정을 거친 이후에 상아질 잔사의 제거 효율을 비교하기 위하여 퍼티 인상재를 제거하고 치아를 다시 두 개로 분리하였다. 입체현미경(SZ4045; Olympus, Tokyo, Japan)으로 20 배 확대하여 두 절편의 근관벽을 촬
영하고 $\mathrm{PC}$ 로 이미지를 전송하였다. 잔존하는 상아질 잔 사의 양의 평가는 어떠한 세정 방법이 사용되었는지 모 르는 검사관에 의해 시행되었다. 이미지 상에서 구와 함 요에 잔존하는 상아질 잔사의 양은 0 - 3으로 점수화되 는 scoring system을 이용하여 평가되었다. 잔존 상아질 잔사의 양을 평가하는 방법으로, ${ }^{10} 0$ 에서 3 까지 단계별로 점수가 존재하며 score가 높을수록 잔사의 양이 많은 것 을 의미한다(Fig. 2).

Score system of remained dentine debris

1. score 0 ; 구나 와동 내에 잔사가 없음

2. score 1; 절반 이하로 잔사가 존재

3. score 2; 절반 이상 잔사가 존재

4. score 3 ; 와동 전체가 잔사로 채워짐

각 군에서 잔존하는 상아질 잔사의 score에 대한 차이 는 95\%의 유의수준에서 Kruskal-Wallis test와 MannWhitney U-test를 사용하여 분석하였다. 

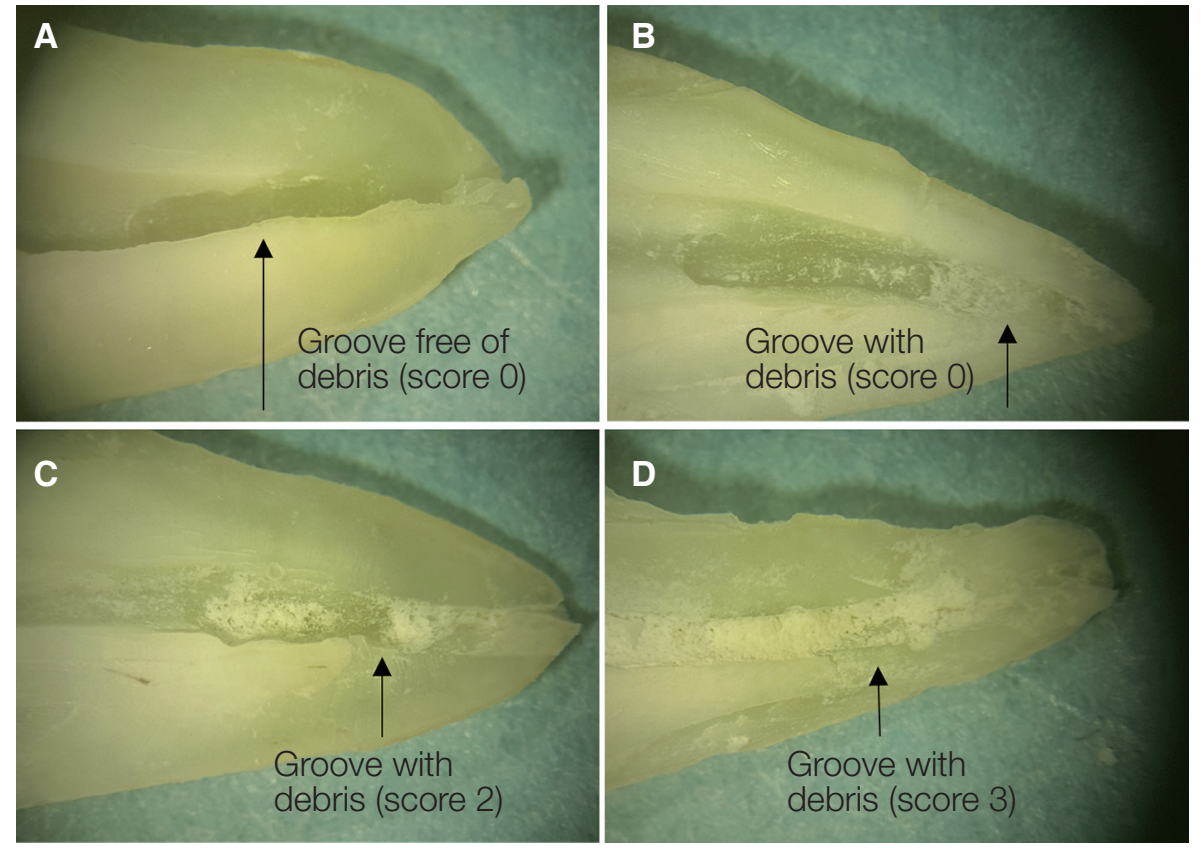

Fig. 2. Specimens after irrigation. Each sample represents a score according to the amount of remained dentin debris. (A) score 0 , (B) score 1, (C) score 2, (D) score 3. Original magnification $\times 20$.

\section{결과}

각 실험군의 구와 함요에서 근관세정 후 잔존 상아질 잔사의 양에 대해 Table 1에 나타내었고, Kruskal-Wallis test와 Mann-Whitney U-test를 사용하여 군 내, 군 간의 통계적 유의성에 대한 분석 결과를 Table 2, 3에 나타내 었다. 수동적 세정과 수동적 초음파 세정의 비교에 대한 통계적 분석 결과는 Table 4에 나타내었다. 구에서는 수
동적 세정과 수동적 초음파 세정 간의 유의한 차이는 없 었다 $(P=0.060)$. 치근첨에서 $6 \mathrm{~mm}$ 떨어진 함요에서는 수동적 세정에 비해 수동적 초음파 세정을 했을 때 잔존 상아질 잔사의 양이 적었다 $(P=0.004)$. 반면 치근첨에서 $2,4 \mathrm{~mm}$ 떨어진 함요에서는 수동적 세정과 수동적 초음 파 세정간의 유의한 차이는 없었다 $(2 \mathrm{~mm} ; P=0.052,4$ $\mathrm{mm} ; P=0.228)$.

Table 1. Numbers of debris score on each group

\begin{tabular}{|c|c|c|c|c|c|}
\hline Group & Score & Grooves & Holes $6 \mathrm{~mm}$ from apex & Holes $4 \mathrm{~mm}$ from apex & Holes $2 \mathrm{~mm}$ from apex \\
\hline $\begin{array}{c}\text { PI } \\
(n=10)\end{array}$ & $\begin{array}{l}0 \\
1 \\
2 \\
3\end{array}$ & $\begin{array}{l}2 \\
3 \\
5 \\
0\end{array}$ & $\begin{array}{l}4 \\
6 \\
0 \\
0\end{array}$ & $\begin{array}{l}2 \\
3 \\
3 \\
2\end{array}$ & $\begin{array}{l}1 \\
3 \\
3 \\
3\end{array}$ \\
\hline $\begin{array}{c}\text { PUI } \\
(\mathrm{n}=10)\end{array}$ & $\begin{array}{l}0 \\
1 \\
2 \\
3\end{array}$ & $\begin{array}{l}5 \\
4 \\
1 \\
0\end{array}$ & $\begin{array}{c}10 \\
0 \\
0 \\
0\end{array}$ & $\begin{array}{l}5 \\
4 \\
1 \\
0\end{array}$ & $\begin{array}{l}1 \\
6 \\
2 \\
1\end{array}$ \\
\hline $\begin{array}{l}\text { Positive control } \\
\qquad(\mathrm{n}=5)\end{array}$ & $\begin{array}{l}0 \\
1 \\
2 \\
3\end{array}$ & $\begin{array}{l}0 \\
0 \\
0 \\
5\end{array}$ & $\begin{array}{l}0 \\
0 \\
0 \\
5\end{array}$ & $\begin{array}{l}0 \\
0 \\
0 \\
5\end{array}$ & $\begin{array}{l}0 \\
0 \\
0 \\
5\end{array}$ \\
\hline $\begin{array}{l}\text { Negative control } \\
\qquad(\mathrm{n}=5)\end{array}$ & $\begin{array}{l}0 \\
1 \\
2 \\
3\end{array}$ & $\begin{array}{l}5 \\
0 \\
0 \\
0\end{array}$ & $\begin{array}{l}5 \\
0 \\
0 \\
0\end{array}$ & $\begin{array}{l}5 \\
0 \\
0 \\
0\end{array}$ & $\begin{array}{l}5 \\
0 \\
0 \\
0\end{array}$ \\
\hline
\end{tabular}

PI, passive irrigation; PUI, passive ultrasonic irrigation. 
Table 2. Mann-Whitney U-test result on debris scores of PI

\begin{tabular}{|c|c|c|c|c|}
\hline & Grooves & Holes $6 \mathrm{~mm}$ from apex & Holes $4 \mathrm{~mm}$ from apex & Holes $2 \mathrm{~mm}$ from apex \\
\hline Grooves & & & & \\
\hline Holes $6 \mathrm{~mm}$ from apex & $0.043 *$ & & & \\
\hline Holes $4 \mathrm{~mm}$ from apex & 0.691 & $0.044 *$ & & \\
\hline Holes $2 \mathrm{~mm}$ from apex & 0.266 & $0.008 *$ & 0.530 & \\
\hline
\end{tabular}

*Value with statistically significant difference $(P<0.05)$.

PI, passive irrigation.

Table 3. Mann-Whitney U-test result on debris scores of PUI

\begin{tabular}{ccccc}
\hline & Grooves & Holes 6 mm from apex & Holes 4 mm from apex & Holes 2 mm from apex \\
\hline Grooves & & & & \\
Holes 6 mm from apex & $0.012^{*}$ & & & \\
Holes 4 mm from apex & 1.000 & $0.012^{*}$ & 0.054 & \\
Holes 2 mm from apex & 0.054 & $0.000^{*}$ & 0 & 0.050 \\
\hline
\end{tabular}

*Value with statistically significant difference $(P<0.05)$.

PUI, passive ultrasonic irrigation.

Table 4. Mann-Whitney U-test result on debris scores between PI and PUI

\begin{tabular}{ccccc}
\hline & Grooves & Holes 6 mm from apex & Holes $4 \mathrm{~mm}$ from apex & Holes 2 mm from apex \\
\hline Significance & 0.060 & $0.004^{*}$ & 0.052 & 0.228 \\
\hline
\end{tabular}

*Values with statistically significant difference $(P<0.05)$.

PI, passive irrigation; PUI, passive ultrasonic irrigation.

\section{고찰}

근관 형성 시 다양한 기구들이 사용된다. 수동기구와 radial land 를 가지고 있는 회전식 기구의 근관 성형은 원 형으로 형성하는 경향이 있다. ${ }^{15}$ 이러한 원형의 근관 성형 은 기구조작이 안된 부위를 남겨둔 채 긴 타원형의 중심 부 혹은 한 쪽 부위에서 형성된다. ${ }^{16-18}$ 게다가 많은 구치 부는 복잡한 해부학적 형태와 isthmus 등의 자연적인 불 규칙성을 가지고 있으며, 기구가 닿지 못한 부분은 근관 세정이 어렵고 근관치료의 실패를 야기할 수 있다. ${ }^{19}$

본 실험에서는 근관의 인공적인 irregularity와 extension 부위에서 상아질 잔사를 제거하는 효율에 대 해 평가하였다. ${ }^{10}$ 근관 내에 기구조작이 안된 extension을 표현하기 위하여 근관 벽에 치근첨으로부터 $2-6 \mathrm{~mm}$ 거 리에 구를, 기구조작이 안된 irregularity를 표현하기 위해 근관 벽에 치근첨으로부터 $2,4,6 \mathrm{~mm}$ 거리에 함요를 형 성하였다.
각 치아를 두 개로 분리하고 근관벽에 구와 함요를 형 성할 때 치아에 균열이나 파절이 발생하지는 않았는지 확인하기 위하여 본 실험에 사용된 시편과는 별도로 12 개의 치아를 가지고 pilot study를 시행하였다. 근관 형성 과 치아의 절단, 근관 세정 등의 과정을 거친 이후에 입체 현미경으로 촬영한 이미지 상에서 절편의 단면과 근관벽 에 결손부위 같은 손상이나 미세균열은 관찰되지 않았 다.

이전 연구에서는 근관 형성과 세정을 한 이후에만 잔 사의 양을 평가하거나, ${ }^{20}$ 음성대조군 없이 세정 전 후로 평가한 반면, ${ }^{10,21}$ 본 실험에서는 상아질 잔사를 채워 넣고 세정을 하지 않은 양성대조군과 상아질 잔사를 채워 넣 지 않은 음성대조군도 평가하였다. 이는 세정 전에 근관 을 형성하면서 존재하는 상아질 잔사를 확인할 수 있고, 상아질 잔사를 주입할 때 충분한 양의 잔사가 적절한 깊 이 및 부위까지 위치하였는지 확인 할 수 있는 실험 방법 이라 생각된다. 
실험 결과값을 정리해보면, 표준화된 구에서는 두 세정 방법 간의 유의한 차이가 없었다(Table 4). 치근첨에서 2 , $4 \mathrm{~mm}$ 거리의 함요에서도 유의한 차이 없었으나, 치근첨 에서 $6 \mathrm{~mm}$ 떨어진 함요에서만 수동적 초음파 세정이 수 동적 세정에 비해 상아질 잔사 제거 효율이 유의하게 높 았다(Table 4).

치근의 중앙 $1 / 3$ 에 해당하는 위치이자 치근첨에서 6 $\mathrm{mm}$ 거리의 함요에서 수동적 초음파 세정을 사용한 방 법이 수동적 세정에 비해 상아질 제거 효율이 높은 결과 를 나타낸 것은 비슷한 디자인으로 수동적 초음파 세정 에 대한 실험을 한 이전의 연구 ${ }^{21,22}$ 와 일치한 결과였다. 이 에 대한 이유는 세척액을 초음파와 함께 쓰면 flushing action이 더 강화되고 상아질 잔사 제거 효율성이 증가 하기 때문이다. 초음파 세정을 하는 동안 근관 내에서 더 많은 양의 세척액이 더 빠른 흐름을 만들게 된다. ${ }^{23,24}$

근관 세정의 효율성은 세정제의 조직 용해도와 기계적 인 활성에 달려있고 근관세정제의 flushing action은 근 관으로부터 유기물과 상아질 잔사, 미생물을 제거하는데 효율적이다. 심지어 세정제의 조직 용해도보다 flushing action 이 더 중요하다고 보고된 바 있고 ${ }^{25}$ 세정제의 활성 화를 통해 근관 내 세정제의 조직 용해도를 증가시킨다 는 연구결과도 있었다. ${ }^{26}$

근관 세정제의 flushing action은 초음파를 사용하여 강화할 수 있으며, 이는 근단부에서 치관부로 직선적인 흐름이 형성되고 진동하는 기구로 인한 음향유동으로 발 생하는 소용돌이는 기구의 첨단 주위에서 더 빠르고 크 다. ${ }^{23,24}$ 한 연구에서는 근관 세정제로서 생리식염수를 사 용하여 수동적 세정의 flushing action과 초음파를 비교 하였다. 초음파는 근관 내의 세균포자를 $86 \%$ 제거한 반 면 수동적 세정은 $62 \%$ 제거 하였다. ${ }^{27}$

반면, 구에서와 치근의 치근단 $1 / 3$ 에 해당하는, 치근첨 에서 2, $4 \mathrm{~mm}$ 거리의 함요에서 두 가지 형태의 세정 방법 은 상아질 잔사 제거에 있어 유의한 차이를 보이지 않았 는데, 이는 여러 연구와는 상반된 결과를 나타낸다. ${ }^{10,22}$

이러한 결과를 나타내게 된 원인은 첫째로, 스코어링 시스템이 0 - 3까지 단계별로 나타내어 실험값의 편차가 커지게 되기 때문으로 생각된다. 잔존하는 상아질 잔사 의 양은 단계적인 수치로 나타내는 데에는 한계가 있고 연속적인 데이터가 더 정확하게 나타낼 수 있다. 따라서 더 정확한 비교를 위해서는 더 세분화된 평가 방법이나 정량적인 측정 방법이 필요하다.

두번째 원인으로 추측되는 것은 본 연구의 표본으로
사용된 하악 소구치가 넓고 만곡이 크지 않은 근관을 가 지고 있지만, 이전의 연구 ${ }^{10}$ 에서 사용한 견치와 비교하면 더 좁고 복잡하며 만곡된 근관을 갖는다는 것이다. 이 원 인은 치근첨에 가까워질수록 세정 효과는 두 세정 방법 모두에서 떨어진다는 실험 결과로부터 더 타당성 있는 주장이라고 볼 수 있다. 특히 수동적 초음파 세정 시 첨 단은 근관벽과 떨어져 있어야 근관벽에 손상을 주지 않 고 음향유동을 발생시켜 효율적인 세정이 가능하다. 하 지만 치근첨에 가까워질수록 근관이 좁아지고 만곡이 되 는 경향이 있어 초음파 팁이 근관벽에 접촉하기 쉬워지 며, 이로 인해 음향유동과 공동효과가 감소될 수 있다. 또한 근관의 근단부에서 치관부에 비해 세척액의 흐름성 이 줄어들기 때문이기도 하다. 따라서 정량적인 측정 방 법, 초음파 기구 팁의 위치에 따른 영향, 근관의 너비와 만곡도 등 이러한 것들의 변수로 둔 추가적인 연구가 더 필요할 것이다.

근관 형성시 최종 치근단 확대 크기는 Protaper Universal system F4 (\#40/.06)로 성형하였다. 연구에 따르면 하 나의 근관을 가진 하악 소구치의 치근첨에서 $1 \mathrm{~mm}$ 상 방에서의 평균 근관 직경은 근원심 $(0.28 \mathrm{~mm})$ 에 비해 협 설 $(0.35 \mathrm{~mm})$ 로 더 길다고 하였다. ${ }^{14}$ 또한 초음파 세정시 사용한 UC-ONE tip (Epdent, Seoul, Korea)의 직경은 $0.25 \mathrm{~mm}$ (zero taper)로 자유로운 진동 운동을 위해서는 이보다 크게 확대된 직경의 근관이 필요하다. 이에 따라 본 실험에서 최종 치근단 크기를 $0.4 \mathrm{~mm}$ 까지 확대하였 다.

적절한 근관세정세의 양은 각 기구의 사용마다 $2 \mathrm{~mL}$ 의 $\mathrm{NaOCl}$ 을 적용하는 것이라고 보고 하였고, ${ }^{8}$ 한 연구 에서는 최종 세정은 5-10 mL을 사용하는 것을 권장하 였다. ${ }^{28}$ 이러한 연구를 토대로 같은 상황을 재현하기 위 하여 세정액의 양을 정량화하였다. 초음파 세정시 초 음파 기구는 두 번을 사용하였고, 사용 전후로 $2 \mathrm{~mL}$ 의 $\mathrm{NaOCl}$ 으로 세정하였기 때문에 모든 실험군에 사용한 세정액의 양을 같게 하기 위하여 총 $14 \mathrm{~mL}$ 의 $\mathrm{NaOCl}$ 이 세정액으로 사용되었다. 분 당 $15 \mathrm{~mL}$ 양의 세정액의 흐 름으로 원활한 세정 작용이 이루어진다는 보고에 따라. ${ }^{29}$ 27 - gauge tip으로 약 1분간 세정하였다(irrigant delivery rate: $15 \mathrm{~mL} \mathrm{~min}^{-1}$ ).

수동적 초음파 세정 방법으로 세정을 할 때 UC-ONE \& UC-ONE tip (Epdent, Seoul, Korea)을 사용하였다. 제조사의 설명에 따르면, 근관 내 상아질 벽에 위해를 가 하지 않으며 안전하게 세정가능하고 $30 \mathrm{kHz}$ 로 진동하여 
조직 잔사의 세정 효율을 증가시킨다는 장점이 있다. 작 동시킬 때 한번에 20 초씩 진동하며, 제조사에서는 진동 후 세정 과정을 두 번 이상 반복하는 것을 권장하고 있 어 이 연구에서도 두 번 초음파 세정을 시행하였고 초음 파 기구의 적용 전 후로 $2 \mathrm{~mL}$, 최종 세정으로 $10 \mathrm{~mL}$ 의 $\mathrm{NaOCl}$ 로 세정하였다.

근관 세정 전 상아질 잔사를 위치시키기 위하여 round bur 로 근관벽의 상아질을 삭제하였고, 그로 인해 인위적 으로 만들어진 상아질 잔사를 사용하였다. 이는 실제 임 상에서 생활 치수 혹은 괴사된 치수가 존재하는 치아를 근관치료하는 경우에 수동 혹은 전동식 근관 확대 기구 를 이용하여 근관 형성을 할 때 발생하는 상아질 잔사와 는 성상이 다르다. 따라서 본 실험에서는 임상에서의 상 황을 정확하게 재현하지는 못하였다는 한계가 있을 수 있다.

\section{결론}

본 실험에서 PI와 PUI 시 근관의 중앙 $1 / 3$ 에서는 상아 질 잔사가 유의하게 적게 남았으며, PUI 시 PI 보다 더 많은 양의 상아질 잔사를 제거했다. 하지만 치근단 $1 / 3$ 에서는 PUI와 PI의 유의한 차이가 없다는 결과가 나왔 다. 따라서 근관 세정시 치근단부의 상아질 잔사 제거 효 용성에 대해서 추가적인 연구가 필요할 것이다.

\section{Acknowledgements}

이 논문은 2016년도 강릉원주대학교 학술연구조성비 지원에 의하여 수행되었다.

\section{ORCID}

Jeong-Hyeon Kim http://orcid.org/0000-0002-80860902

Jin-Woo Kim http://orcid.org/0000-0002-0004-0710 Kyung-Mo Cho http://orcid.org/0000-0003-3464-9425

Se-Hee Park http://orcid.org/0000-0002-4052-4082

\section{References}

1. Baugh D, Wallace J. The role of apical instrumentation in root canal treatment: a review of the litera- ture. J Endod 2005;31:333-40.

2. Moorer WR, Wesselink PR. Factors promoting the tissue dissolving capability of sodium hypochlorite. Int Endod J 1982;15:187-96.

3. Hand RE, Smith ML, Harrison JW. Analysis of the effect of dilution on the necrotic tissue dissolution property of sodium hypochlorite. J Endod 1978;4: 60-4.

4. Byström A, Sundqvist G. Bacteriologic evaluation of the effect of 0.5 percent sodium hypochlorite in endodontic therapy. Oral Surg Oral Med Oral Pathol 1983;55:307-12.

5. Walker A. A definite and dependable therapy for pulpless teeth. J Am Dent Assoc 1936;23:1418-25.

6. Abou-Rass M, Piccinino MV. The effectiveness of four clinical irrigation methods on the removal of root canal debris. Oral Surg Oral Med Oral Pathol 1982;54:323-8.

7. Chow TW. Mechanical effectiveness of root canal irrigation. J Endod 1983;9:475-9.

8. Walters MJ, Baumgartner JC, Marshall JG. Efficacy of irrigation with rotary instrumentation. J Endod 2002;28:837-9.

9. Sabins RA, Johnson JD, Hellstein JW. A comparison of the cleaning efficacy of short-term sonic and ultrasonic passive irrigation after hand instrumentation in molar root canals. J Endod 2003;29: 674-8.

10. Lee SJ, Wu MK, Wesselink PR. The effectiveness of syringe irrigation and ultrasonics to remove debris from simulated irregularities within prepared root canal walls. Int Endod J 2004;37:672-8.

11. Goodman A, Reader A, Beck M, Melfi R, Meyers W. An in vitro comparison of the efficacy of the step-back technique versus a step-back/ultrasonic technique in human mandibular molars. J Endod 1985;11:249-56.

12. Siqueira JF Jr, Lopes HP. Mechanisms of antimicrobial activity of calcium hydroxide: a critical review. Int Endod J 1999;32:361-9.

13. Wu MK, Wesselink PR. A primary observation on the preparation and obturation of oval canals. Int Endod J 2001;34:137-41.

14. Wu MK, R'oris A, Barkis D, Wesselink PR. Prevalence and extent of long oval canals in the apical 
third. Oral Surg Oral Med Oral Pathol Oral Radiol Endod 2000;89:739-43.

15. Hülsmann M, Schade M, Schäfers F. A comparative study of root canal preparation with HERO 642 and Quantec SC rotary Ni-Ti instruments. Int Endod J 2001;34:538-46.

16. Walton RE. Histologic evaluation of different methods of enlarging the pulp canal space. J Endod 1976;2:304-11.

17. Peters OA, Laib A, Göhring TN, Barbakow F. Changes in root canal geometry after preparation assessed by high-resolution computed tomography. J Endod 2001;27:1-6.

18. Ardila CN, Wu MK, Wesselink PR. Percentage of filled canal area in mandibular molars after conventional root-canal instrumentation and after a noninstrumentation technique (NIT). Int Endod J 2003;36:591-8.

19. De-Deus G, Barino B, Zamolyi RQ, Souza E, Fonseca A Jr, Fidel S, Fidel RA. Suboptimal debridement quality produced by the single-file F2 ProTaper technique in oval-shaped canals. J Endod 2010;36:1897-900.

20. Lumley PJ, Walmsley AD, Walton RE, Rippin JW. Cleaning of oval canals using ultrasonic or sonic instrumentation. J Endod 1993;19:453-7.

21. van der Sluis LW, Gambarini G, Wu MK, Wesselink PR. The influence of volume, type of irrigant and flushing method on removing artificially placed dentine debris from the apical root canal during passive ultrasonic irrigation. Int Endod J 2006;39:472-6.
22. Layton G, Wu WI, Selvaganapathy PR, Friedman S, Kishen A. Fluid dynamics and biofilm removal generated by syringe-delivered and 2 ultrasonic-assisted irrigation methods: a novel experimental approach. J Endod 2015;41:884-9.

23. Ahmad M, Pitt Ford TJ, Crum LA. Ultrasonic debridement of root canals: acoustic streaming and its possible role. J Endod 1987;13:490-9.

24. Stock CJ. Current status of the use of ultrasound in endodontics. Int Dent J 1991;41:175-82.

25. Baker NA, Eleazer PD, Averbach RE, Seltzer S. Scanning electron microscopic study of the efficacy of various irrigating solutions. J Endod 1975;1:12735.

26. Conde AJ, Estevez R, Loroño G, Valencia de Pablo Ó, Rossi-Fedele G, Cisneros R. Effect of sonic and ultrasonic activation on organic tissue dissolution from simulated grooves in root canals using sodium hypochlorite and EDTA. Int Endod J 2016 Nov 3. doi: 10.1111/iej.12717. [Epub ahead of print]

27. Cunningham W'T, Martin H, Pelleu GB Jr, Stoops DE. A comparison of antimicrobial effectiveness of endosonic and hand root canal therapy. Oral Surg Oral Med Oral Pathol 1982;54:238-41.

28. Santos MD, Walker WA 3rd, Carnes DL Jr. Evaluation of apical seal in straight canals after obturation using the Lightspeed sectional method. J Endod 1999;25:609-12.

29. van der Sluis L, Wu MK, Wesselink P. Comparison of 2 flushing methods used during passive ultrasonic irrigation of the root canal. Quintessence Int 2009;40:875-9. 


\section{근관치료 시 초음파 세정 기술을 이용한 잔사 제거의 효율성}

\section{김정현, 김진우, 조경모, 박세희*}

강릉원주대학교 치과대학 치과보존학교실

목적: Passive irrigation (PI)과 Passive ultrasonic irrigation (PUI)의 상아질 잔사 제거 효율성을 비교하는 것이다.

연구 재료 및 방법: $16 \mathrm{~mm}$ 길이로 표준화된 하악 소구치 치근을 근관 확대 후 종단으로 이등분 하였다. 분리된 한쪽 상 아질벽에는 길이 $4 \mathrm{~mm}$, 너비 $0.2 \mathrm{~mm}$, 깊이 $0.5 \mathrm{~mm}$ 의 표준화된 구를 형성하였고, 반대쪽에는 직경 $0.3 \mathrm{~mm}$, 깊이 $0.5 \mathrm{~mm}$ 인 3개의 반구 형태의 함요를 형성하였다. 각 구와 함요에는 $\mathrm{NaOCl}$ 과 혼합된 상아질 잔사로 채우고, 퍼티 인상재를 사용 하여 재조합하였다. Group 1은 PI를 이용하고 Group 2는 PUI를 이용하여 각 근관내를 세정하였다. 현미경과 디지털카 메라로 절편의 근관벽을 촬영하고, 구와 함요에 잔존하는 상아질 잔사의 양을 scoring system을 이용하여 평가하였다.

결과: 근관의 중앙 $1 / 3$ 에서 group 1 이 group 2 에 비해 잔사를 더 많이 제거하였지만, 치근단부에서는 유의한 차이가 없 었다.

결론: 하악 소구치에서 근관에 기구가 닿지 못하는 부위를 세정시, 근관의 중앙 $1 / 3$ 에서 PUI를 사용하는 것이 PI에 비해 상아질 잔사의 제거 효율이 우수했지만, 치근단부에서는 PUI와 PI의 유의한 차이가 없었다.

(구강회복응용과학지 2017;33(2):97-105)

주요어: 근관 세정, 상아질 잔사, 하악 소구치, 수동적 세정, 수동적 초음파 세정 